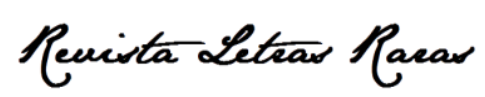

ISSN: 2317-2347 - v. 9, n. 4 (2020)

Todo o conteúdo da RLR está licenciado sob Creative Commons Atribuição 4.0 Internacional

\title{
O invisível dos olhos
}

Cleane da Silva de Lima*

Mestranda em Literatura pela Universidade Federal do Piauí- UFPI, bolsista FAPEPI.

iD http:/orcid.org/0003-4114-3924

Recebido: 27 jun. 2020. Aprovado: 18 set. 2020.

\section{Como citar este texto:}

LIMA, Cleane da Silva de. 0 invisível dos olhos. Revista Letras Raras. Campina Grande, v. 9, n. 4, p. 383-385, dez. 2020.

"Não há nada mais estranho que começar a falar das minhas fraquezas, ou quem, por assombro, vomita palavras sãs e doentias. Não compreendo o invisível dos olhos das pessoas, elas estão sempre assim, estranhas. Bauman tinha razão e atesto que este mundo pirou. Não, não ouse me dizer, ou conformar com palavrinhas de positividade que só servem para serem ditas e não mudam porcaria nenhuma. Não quero palavras inúteis que servem para alimentar 0 ego de vocês como uma ajuda, eu quero prática. Palavras vazias servem para nada. Pratique-as com práticas". Bati a porta com força quando saí. A decepção devastou minha alma.

Estas foram minhas últimas palavras quando, definitivamente, arrisquei um palpite verdadeiro. Para falar a verdade, aquele dia estava muito estranho. Estava mesmo. Saí pela rua, observando o barulho da poeira do asfalto, dos carros, dos sons dos pés das pessoas, das crianças birrentas, dos idosos com seus passos dificultosos, e um erro de pessoas sendo gentis. Perdão, mas "um erro de pessoas", em minha boca, tem a significância de pouquíssimas pessoas que se importam com o próximo. Chamo de erro uma pessoa que é gentil sem pedir nada em troca. Sabe, é difícil conviver com pessoas gentis e simples, parece um erro elas existirem. Elas são raras de se encontrar. Para falar a verdade, estou muito confuso mesmo,

$\triangle$ necah.lima@hotmail.com 


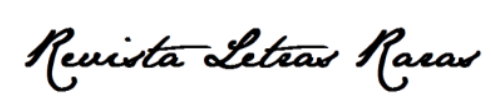

ISSN: 2317-2347 - v. 9 , n. 4 (2020)

Todo o conteúdo da RLR está licenciado sob Creative Commons Atribuição 4.0 Internacional

sobre tudo neste mundo. "As pessoas estão loucas lá fora", essa frase do filme do Coringa, interpretado por Joaquin Phoenix, descreveu as pessoas. 0 mundo está louco, ou sempre esteve?

Olho para tudo que é lado, e nada me agrada, a não ser um cachorro muito gentil que é mais inteligente e humano que muita gente, e mais amistoso. O cachorro tem muito mais humanidade que muitos deste mundo. Por falar de mundo, quais são as últimas tendências da música? Da moda? Pode me dizer se a tendência da equidade, resiliência, amor está em alta? Ou é um artigo de luxo? Parece que ser gentil, neste mundo, é contemplação de uma epifania de bonança como algo, uma tarefa difícil de ser executada e quando é, causa grande admiração. Digo-te: ser gentil é a coisa mais simples do mundo e todo mundo devia praticar mais vezes. Assim como pratica sexo, assim como canta, come, dorme e defeca. Era para ser algo natural. 0 mundo sempre foi assim doido e egoísta?

A expiação é muito mais praticada do que a gentileza, parece que culpar e se esquivar da culpa é mais importante do que reconhecer a própria falta de caráter e dignidade. O homem é o próprio demônio disfarçado de homem. Que culpa este mundo tem? Ao mesmo tempo... Olhe para o céu. Olhe! Dói nos olhos. O sol dói no corpo, pisar no asfalto quente é desconfortável. Acho que ressentimento, remorso, arrependimento é raro ser visto no invisível dos olhos das pessoas. Mas eles existem. Existe ainda caráter e dignidade. Gentileza. Aquele erro ali, quando ajudou o idoso, tem humanidade. São as pequenas coisas e simples que se tornam máximas. Não precisa de muito para fazer o que é bom e o certo. O simples é mais gratificante. Gratidão.

Estou vivo, ouça a minha respiração, arrastada. Cansado, deplorável. Parece que a multidão precisa culpar alguém, este fica na linha de frente sendo culpado, enquanto muitos descarregam seus erros e suas futilidades nas costas dos outros. Estou morto. Morri neste mundo, sem prática, só falatório de pessoas que reclamam, dizem coisas e não praticam o que devem, apenas culpam. Ouvi que reclamar e culpar sem uma solução para aquilo que critica é inútil e imbecil. Estou morto. Mas, rezo que a gentileza seja natural como sentir fome. 0 mundo está passando fome e morrendo. E os "expiadores" estão culpando e fazendo nada. Pura hipocrisia. Eu sou hipócrita também. Morri antes de ser gentil. Calçada quente, eu estou morto e farto de mim, de tudo. 0 mundo se perdeu. 0 mundo foi morto pelo homem, ou quase morto. Não, ainda não morreu de vez, porque ainda têm alguns bons erros no meio destes homens egoístas. Preciso salvar alguém, e que alguém me salve. Por favor, salvemo-nos, eu imploro. 
Morri ali na companhia do cachorro, nos braços de um mendigo que, por ventura, dei-lhe a mão e me disse:

- Calma, estou aqui. Vá com Deus! Quem você ajudou será eternamente grato por tudo.

- Qual seu nome? - As palavras saíram pelos meus olhos embaçados.

- Resiliência!

Ele, nos últimos momentos, passou a acreditar que ainda existe salvação para este mundo. Há muito tempo não enxergava bonança. Os olhos conseguiram enxergar o invisível nos olhos do mendigo e do cachorro. Compreendeu o invisível dos olhos daquele homem. E poucos segundos, os seus olhos se fecharam. Adeus! 